\title{
An evaluation of carbon offset supplementation options for beef production systems on coastal speargrass in central Queensland, Australia
}

\author{
D. Cottle ${ }^{\mathrm{A}, \mathrm{D}}$, R. Eckard $^{\mathrm{B}}$, S. Bray ${ }^{\mathrm{C}}$ and M. Sullivan ${ }^{\mathrm{C}}$ \\ ${ }^{A}$ School of Environmental and Rural Science, University of New England, Armidale, NSW 2351, Australia. \\ ${ }^{B}$ Faculty of Veterinary and Agricultural Sciences, The University of Melbourne, Parkville, Vic. 3010, Australia. \\ ${ }^{C}$ Department of Agriculture and Fisheries, PO Box 6014, Rockhampton MC, Qld 4702, Australia. \\ DCorresponding author. Email: david.cottle@une.edu.au
}

\begin{abstract}
In 2014, the Australian Government implemented the Emissions Reduction Fund to offer incentives for businesses to reduce greenhouse gas (GHG) emissions by following approved methods. Beef cattle businesses in northern Australia can participate by applying the 'reducing GHG emissions by feeding nitrates to beef cattle' methodology and the 'beef cattle herd management' methods. The nitrate $\left(\mathrm{NO}_{3}\right)$ method requires that each baseline area must demonstrate a history of urea use. Projects earn Australian carbon credit units (ACCU) for reducing enteric methane emissions by substituting $\mathrm{NO}_{3}$ for urea at the same amount of fed nitrogen. $\mathrm{NO}_{3}$ must be fed in the form of a lick block because most operations do not have labour or equipment to manage daily supplementation. $\mathrm{NO}_{3}$ concentrations, after a 2-week adaptation period, must not exceed $50 \mathrm{~g} \mathrm{NO}_{3}$ /adult animal equivalent per day or $7 \mathrm{~g} \mathrm{NO}_{3} / \mathrm{kg}$ dry matter intake per day to reduce the risk of $\mathrm{NO}_{3}$ toxicity. There is also a 'beef cattle herd management' method, approved in 2015, that covers activities that improve the herd emission intensity (emissions per unit of product sold) through change in the diet or management. The present study was conducted to compare the required ACCU or supplement prices for a $2 \%$ return on capital when feeding a low or high supplement concentration to breeding stock of either (1) urea, (2) three different forms of $\mathrm{NO}_{3}$ or (3) cottonseed meal (CSM), at $\mathrm{N}$ concentrations equivalent to 25 or $50 \mathrm{~g}$ urea/animal equivalent, to fasten steer entry to a feedlot (backgrounding), in a typical breeder herd on the coastal speargrass land types in central Queensland. Monte Carlo simulations were run using the software @ risk, with probability functions used for (1) urea, $\mathrm{NO}_{3}$ and CSM prices, (2) GHG mitigation, (3) livestock prices and (4) carbon price. Increasing the weight of steers at a set turnoff month by feeding CSM was found to be the most cost-effective option, with or without including the offset income. The required ACCU prices for a $2 \%$ return on capital were an order of magnitude higher than were indicative carbon prices in 2015 for the three forms of $\mathrm{NO}_{3}$. The likely costs of participating in ERF projects would reduce the return on capital for all mitigation options.
\end{abstract}

Additional keywords: cottonseed meal, Emissions Reduction Fund, greenhouse gases, Monte Carlo simulation, nitrates.

Received 12 August 2015, accepted 25 November 2015, published online 9 February 2016

\section{Introduction}

In 2014, the Australian Government implemented the Emissions Reduction Fund (ERF) to offer incentives for Australian businesses to adopt practices to cut the amount of greenhouse gases (GHG) they create (DoE 2015a). The fund operates by businesses following approved methods to generate Australian carbon credit units (ACCU), which can then be sold to generate business revenue. Under the ERF, two offset methods have been approved that are targeted at beef cattle production. One is to credit enteric methane reduction by feeding nitrate $\left(\mathrm{NO}_{3}\right)$ to beef cattle (Comlaw 2014). A new offset method, the 'beef cattle herd management' (DoE 2015b), has also been approved to credit activities that improve the herd emission intensity (EI, emissions per unit of product sold). It includes activities that improve the diet or management of a pasture-fed herd, thereby reducing days from birth to slaughter, the average age of the herd or number of animals in the herd.

Cattle production on native speargrass pastures in northern Australia follows a distinctly seasonal pattern, corresponding to that of rainfall and pasture growth, with low or nil growth during the dry winter-spring months, followed by high growth rates early and then moderate growth during the remainder of the wet summer-autumn months (McCown 1980-1981; Bortolussi et al. $2005 b$ ). Cattle producers in the region, when surveyed on future goals for their herds (Bortolussi et al. 2005a), listed increasing turn-off weight and reducing turn-off age of their cattle to increase profitability as major priorities. Beef cattle on low-protein diets, typical of the tropical rangeland systems of Australia, can increase 
their efficiency of utilisation of the poor-quality forage with urea supplementation, usually in the form of a salt or molasses lick (Dixon 2013). The demand for nitrogen (N) and protein is seasonal, with pasture protein being lowest (crude protein 4-6\%) during the drier months (June to December) in northern Australia, then rising with the summer rains (Poppi and McLennan 1995; Bray et al. 2015). This means that urea supplementation could be fed for up to 6 months of the year or during drought periods, so as to sustain growing and/or lactating animals or reduce weight loss (Hennessy et al. 2000).

The $\mathrm{NO}_{3}$ supplementation offset method requires that a business is currently supplementing with urea. The method includes an adaptation period and limits the rate that can be fed to reduce toxicity risks. Supplementing $\mathrm{NO}_{3}$ to ruminants has been shown to decrease methane $\left(\mathrm{CH}_{4}\right)$ production (Leng 2008; van Zijderveld et al. 2011). This is due to $\mathrm{NO}_{3}$ having a greater affinity for $\mathrm{H}_{2}$ than does $\mathrm{CO}_{2}$ (Ungerfeld and Kohn 2006) and, therefore, when $\mathrm{NO}_{3}$ is present in the rumen, nitrite formation is favoured over $\mathrm{CH}_{4}$ production. Stoichiometrically, $1 \mathrm{~kg} \mathrm{NO}$ reduces $\mathrm{CH}_{4}$ formation by $258.7 \mathrm{~g}$. However, in practice, measured $\mathrm{CH}_{4}$ reductions are usually slightly less than this, i.e. efficiency of mitigation is less than 1 (van Zijderveld et al. 2011).

Supplementary feeding with non-protein N (NPN) supplements such as urea and $\mathrm{NO}_{3}$ increases the risk of livestock deaths. To reduce the risk, NPN supplementation needs to follow established guidelines, limiting the amount fed per day and having an acclimatisation period. Leng (2008) suggested that the urea in a lick can be replaced with $\mathrm{NO}_{3}$ as an alternative source of $\mathrm{N}$ for the rumen microbiota, as long as total $\mathrm{NO}_{3}$ intakes do not exceed 10-25 g NO$/ \mathrm{kg}$ dry matter intake (DMI) $\left(0.23-0.57 \% \mathrm{NO}_{3}-\mathrm{N}\right.$ on DM basis or $\left.1-2.5 \mathrm{~g} / \mathrm{kg} \mathrm{LW}^{0.75}\right)$. For a $450 \mathrm{~kg}$ steer consuming $10 \mathrm{~kg}$ DM per day, this means an intake of between 100 and $244 \mathrm{~g} \mathrm{NO}_{3} /$ day. The replacement of urea with an equivalent amount of $\mathrm{NO}_{3}-\mathrm{N}_{\text {means }}$ that $100 \mathrm{~g} \mathrm{NO}_{3}$ equates to $\sim 50 \mathrm{~g}$ urea. While $\mathrm{NO}_{3}$ can be toxic to ruminants, Leng (2008) suggested that nitrite accumulation may be avoided if the rumen microbial population has been acclimatised to $\mathrm{NO}_{3}$ supplementation. The literature on $\mathrm{NO}_{3}$ toxicity is not clear, with Eckard (1990) suggesting toxicity in perennial ryegrass to occur above $0.57-0.60 \% \quad \mathrm{NO}_{3}-\mathrm{N}\left(25-27\right.$ g $\left.\mathrm{NO}_{3} / \mathrm{kg} \mathrm{DMI}\right)$. Callaghan et al. (2014) noted that for $\mathrm{NO}_{3}$ to be adopted in preference to urea-based supplementation in northern Australia beef herds, the return from mitigation (i.e. carbon price and amount of mitigation) needs to cover the additional cost of $\mathrm{NO}_{3}$ supplementation.

Supplementary feeding of cattle is used extensively by cattle producers in northern Australia for a variety of purposes, including, in more recent years, as a strategy to increase growth rates of cattle to meet higher-value market specifications (McLennan 2004). High-lipid, by-product protein meals, such as copra meal, whole cottonseed and palm kernel expeller meal have comparatively limited data on resultant animal performance, but are being increasingly used as alternatives to more conventional bypass protein sources such as cottonseed meal (CSM). The objective of supplementary feeding programs, associated with more extensive grazing systems, is to maximise pasture use, as this is the low-cost component of the diet, and provide additional nutrients through the supplement. The low profit margins in most beef businesses in northern Australia (McLean et al. 2014) mean that any supplementation strategy needs to be closely assessed to ensure the extra costs are more than compensated for by extra productivity or value of product.

We chose to model coastal speargrass production systems, as urea, $\mathrm{NO}_{3}$ and $\mathrm{CSM}$ are all practical beef supplementation options for this area where protein is known to be lacking and urea supplementation is common. The area is generally located in a narrow strip extending along the coastline from Rockhampton to north of Mackay in central Queensland, Australia. As much of this land type is unsuitable for finishing stock, the trend has been for this area to produce store cattle suitable for finishing or backgrounding on more fertile land types (Murphy 1995) or, more recently, in feedlots.

The aim of the present study was to compare the relative GHG mitigation potential and cost benefits of traditional urea supplementation with iso-nitrogenous supplementation of calcium $\mathrm{NO}_{3}$, ammonium $\mathrm{NO}_{3}$ and calcium ammonium $\mathrm{NO}_{3}$, as well as the more conventional CSM supplementation, with a typical beef herd grazing coastal speargrass country in central Queensland.

\section{Materials and methods}

\section{Region modelled}

Coastal speargrass land types in central Queensland, Australia, are a mix of landforms including mountains, ranges and alluvial plains (Tothill and Gillies 1992; DAF 2015a). Tree species include various Eucalyptus, Corymbia and Melaleuca species. Typically, the dominant native pasture species include black speargrass (Heteropogon contortus), bluegrasses (Bothriochloa spp.) and a large number of other native grass and legume species (e.g. Chloris, Panicum, Chyrsopogon, Desmodium species). Introduced grass species have sometimes been established on more fertile land types including Pangola grass, Rhodes grass and Bisset creeping bluegrass. More commonly introduced legumes have been oversown into the native pasture, including stylos and wynn cassia (Murphy 1995). Generally, soils are highly leached and pastures are low in protein for much of the year.

The average annual rainfall for the area is $814 \mathrm{~mm}$, with the majority of rain falling during the summer months (BoM 2015). The main regional saleyards are located at Gracemere, $13 \mathrm{~km}$ west of Rockhampton.

\section{Breedcow}

Regionally relevant northern cattle production herd structure, reproduction rate, growth rate, turn-off weights and profitability were drawn from the templates in Breedcow and Dynama (Holmes 2012; DAF 2015b). Breedcow and Dynama is a steady-state herd model that generates a herd structure based on a starting number of weaner heifers retained for mating each year. Herd structure is then determined by the weaning and death rates and sales from each class of stock. A simulation for a 2000 adult animal equivalent (AE) beef herd was constructed on the basis of the Central Queensland Coastal Speargrass regional template. A herd size of 2000 AE was chosen, because below this herd size, high overhead/AE expenses limit the likelihood of the enterprise being profitable (McLean et al. 2014). This model included feeding of urea in winter-spring (10, 40 and $50 \mathrm{~g}$ urea/day for weaners, heifers and breeders, 
respectively), a common practice in the region (Dixon 2013). This regime was considered the baseline for the analysis (baseline urea). Mean stock sale prices were based on the average price per kilogram of various sex, age and liveweight (LW) classes at the Gracemere saleyards for all available 2015 sales (CQLX 2015). Values for stock LW and LW gains (LWG) were taken from Bray et al. (2015) who collated experimental and property LW and LWG data in the region to generate representative seasonal values. At sale, weaners were assumed to be $180 \mathrm{~kg}$, heifers $270 \mathrm{~kg}, 2-3$ year old (yo) cows $390 \mathrm{~kg}$ and older cows $510 \mathrm{~kg}$, $1-2$ yo steers $310 \mathrm{~kg}$ and bulls $740 \mathrm{~kg}$.

The number of retained cattle (keepers) supplemented for 180 days in winter and spring (June to November) were as follows: 400 female weaners, $2761-2$ yo heifers, $2462-3$ yo mated cows, $7163-11$ yo mated cows, 400 weaners steers and 33 2-6 yo bulls.

\section{Mitigation}

The Australian National Greenhouse Gas Inventory equations (UNFCCC 2015) were used to calculate GHG emissions, modified using the more recent $\mathrm{CH}_{4}(\mathrm{~g} /$ day $)=20.7 \times \mathrm{DMI}$ (kg/day) (Charmley et al. 2016) and the global warming potential for $\mathrm{CH}_{4}$ of 25 times $\mathrm{CO}_{2}$ (DoE 2015b). The stoichiometry of the reduction of $\mathrm{NO}_{3}$ to ammonia is such that $1 \mathrm{~mol}$ of $\mathrm{NO}_{3}$ should produce $1 \mathrm{~mol}$ of ammonia and reduce $\mathrm{CH}_{4}$ production by $1 \mathrm{~mol}$ or

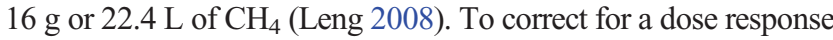
effect, final abatement potential was calculated by multiplying the theoretical mitigation by Eqn 1 (van Zijderveld et al. 2011), if efficiency was less than 1 , which was the case with the higher level of the calcium-based $\mathrm{NO}_{3}$ supplements.

$$
\text { Mitigation efficiency }=1.13-0.17 \times \mathrm{g} \mathrm{NO}_{3} / \mathrm{kgLW}^{0.75} \text {, }
$$

where LW is in kilograms.

A theoretical stochiometry of $1 \mathrm{~kg} \mathrm{NO}_{3}$ reducing $\mathrm{CH}_{4}$ production by $258.7 \mathrm{~g}$ was used (Cottle et al. 2011; Cottle and Eckard 2014). The ERF $\mathrm{NO}_{3}$ supplementation method requires that, for each $\mathrm{NO}_{3}$ supplementation period, except during the 2-week $\mathrm{NO}_{3}$ adaptation period, the rate at which $\mathrm{NO}_{3}$ is fed to a herd must not exceed (1) $50 \mathrm{~g}$ of $\mathrm{NO}_{3}$ per AE per day or (2) $7 \mathrm{~g}$ of $\mathrm{NO}_{3}$ per $\mathrm{kg}$ of DMI per day. At this amount of feeding, no reduction in voluntary intake was expected (Hulshof et al. 2015).

The average carbon price used in the analysis for mitigation was AU\$10/t $\mathrm{CO}_{2}$-e. We reduced the current ERF carbon price of AU\$12.25 (CER 2015b) due to ERF overspending their budget at the first two carbon auctions; so, future prices will likely be lower.

\section{Supplements}

In a 12-month period starting at the beginning of summer (December), stock were supplemented as follows: (1) no supplement (stock sold in June before urea or $\mathrm{NO}_{3}$ supplementation begins); 1-2 yo cull heifers, 3-12 yo unmated cull cows, 7 yo cast for age bulls; (2) supplemented for 180 days in winter and spring; 2-11 yo mated heifers and cows; (3) supplemented for 100 days in late autumn and winter; 1-2 yo steers modelled to be fed urea or $\mathrm{NO}_{3}$ and sold at 310 or $320 \mathrm{~kg}$ in June, or supplemented with CSM and sold at 323,338 or $348 \mathrm{~kg}$ in June. The CSM supplementation scenarios also included supplementation of the other stock in winter and spring at the low or high rates of urea when steers were supplemented with low and high CSM, respectively; the very high rate of CSM was also modelled to be fed the high urea rate. Thus, the high and very high CSM strategy was in combination with the high urea baseline strategy.

Three forms of $\mathrm{NO}_{3}$ blocks were compared with urea blocks modelled to be fed to all kept or mated cull stock in winter and spring. Feeding urea was also compared with feeding CSM to steers in autumn and winter, in addition to urea feeding of kept and mated cull stock in winter and spring, as they would still be supplemented in practice. The three forms of $\mathrm{NO}_{3}$ (as fed) were: (1) calcium $\mathrm{NO}_{3}(\mathrm{CN})$ block, containing $6 \% \mathrm{~N}$ and $26 \% \mathrm{NO}_{3}$; (2) ammonium $\mathrm{NO}_{3}$ (AN) block containing $14 \% \mathrm{~N}$ and $20.8 \% \mathrm{NO}_{3}$, and (3) calcium ammonium $\mathrm{NO}_{3}(\mathrm{CAN})$, containing $27 \% \mathrm{~N}$ and $60 \% \mathrm{NO}_{3}$. The CSM was assumed to be solvent-extracted and contain no dietary lipid affecting mitigation.

The average relative prices of supplements per tonne of $\mathrm{N}$ were AU\$6884 (urea), AU\$23614 (CN), AU\$8744 (AN) and AU $\$ 12530$ (CAN), with CSM priced at AU\$580/t as fed. The urea and $\mathrm{NO}_{3}$ block prices were based on their current, relative, wholesale import prices and the current price of feed blocks containing 30\% urea.

The urea, three $\mathrm{NO}_{3}$ supplements and CSM were modelled to be fed at two iso-nitrogenous concentrations, namely (1) low (11.3 g N/AE.day) and (2) high (22.6 g N/AE.day). While there is some argument about the amount of urea that should be fed, $\sim 50 \mathrm{~g} /$ head.day for breeder cows and $30 \mathrm{~g} /$ head.day for dry and growing cattle will result in improved rumen function of cattle grazing mature grass pastures in northern Australia. CSM was also fed to 1-2 yo steers at a very high rate of $45.2 \mathrm{~g} \mathrm{~N} /$ AE.day, which was twice the high-N rate. Constant intake of supplement by individual animals in each stock class was assumed; however, this would be achieved in practice only by using a controlled, individual feeding system (e.g. Cottle and Wyld 2014). The low N concentrations were in the range of NPN supplementation used in the northern Australian grazing industry (Dixon 2013; Callaghan et al. 2014). The larger amount of urea feeding was considered as the baseline for the study. A recent meta-analysis of dry season NPN supplementation experiments conducted from 1968 to 2004 by Dixon (2011) suggested that beef cattle received supplements for $5.3 \pm 1.8$ months, so we assumed 6 months of supplementation for kept and mated stock.

The LWG response to low $\mathrm{N}$ amounts of urea compared with high $\mathrm{N}$ amounts were set at $10 \mathrm{~kg}$ lower than sale weights at the higher $\mathrm{N}$ amounts. This allowed for compensatory gain and the relative LWGs made on the low versus high urea amounts (Coates and Dixon 2008; Dixon 2011). LWG in response to CSM is described by Eqn 2 (McLennan 2014), as follows:

$$
\mathrm{LWG}=1.186-1.113 \times 0.744^{x},
$$

where LWG is in $\mathrm{kg} /$ day, and $x=\mathrm{g} \mathrm{CSM} / \mathrm{kg} \mathrm{LW}$ per day.

\section{Toxicity and deaths}

The amounts of urea or $\mathrm{NO}_{3}$ modelled to be fed were below rates regarded as toxic (urea $>0.31 \mathrm{~g}$ urea/day.kg LW, $\mathrm{NO}_{3}>1 \mathrm{~g} \mathrm{NO}_{3} /$ day. $\mathrm{LW}^{0.75}$ ) that would have resulted in death rates higher than 
normal. Overall breeder death rates were assumed to be $2.14 \%$ ( $1-4 \%$ for various age classes) for all supplementation strategies in the breedcow files. CSM-related deaths also did not occur as the calculated gossypol amounts in the diet were much less than toxic amounts of $400 \mathrm{mg} / \mathrm{L}$ (Risco et al. 1992).

\section{Analysis with @risk}

Monte Carlo simulations are a standard approach to analyses where multiple uncertainties exist. The software program @)risk (Palisade 2015) was used to run Monte Carlo simulations (10 000 iterations) by fitting normal probability functions with coefficient of variations of $20 \%$ assumed for: (1) livestock prices (AU\$/kg); (2) prices of urea, $\mathrm{NO}_{3}$ and CSM (AU\$/t); (3) carbon offset prices (AU\$ $/ \mathrm{tCO}_{2}-\mathrm{e}$ ); and (4) the predicted mitigation from supplement ( $\mathrm{t} \mathrm{CO}_{2}-\mathrm{e}$ ). The means for total emissions and gross margins (GM)/AE of the options were compared by $z$-tests.

Outputs with resulting distributions were calculated for the $\mathrm{GM} / \mathrm{AE}$ and the return on capital (RoC). Sensitivity analyses were run for $\mathrm{GM} / \mathrm{AE}$ and $\mathrm{RoC}$ for each option. Operating profit was estimated as the GM minus overheads/enterprise costs of AU \$126/AE (AU\$252 000). The implementation and transaction costs associated with ERF projects were not included in the operating-profit calculations. A land value of AU\$3000/AE (Landmark 2015) and herd value of AU\$600/AE (Holmes 2012) were assumed, to calculate the return (operating profit) on capital. The Goal Seeker routine in @ risk was used to calculate the net carbon price and the supplement price needed to achieve a $2.0 \% \pm 0.00005 \%$ RoC within 20 sets of 5000 iterations. The $2.0 \%$ RoC was slightly greater than the average return for feeding the very high amount of CSM, which was the best option of those analysed.

\section{Results}

The GHG production, mitigation and EI (per tonne LW turn-off) estimated for all the options are shown in Table 1. As 10000 iterations were run, most of the mean total emissions of options were significantly different. The most effective mitigation option was a high rate of $\mathrm{CN}$ ( $190.5 \mathrm{t} \mathrm{CO}_{2}$-e), followed by a high rate of $\mathrm{CAN}\left(178.1 \mathrm{t} \mathrm{CO}_{2}-\mathrm{e}\right)$, and then the very high CSM (and urea) supplementation strategy $\left(112.4 \mathrm{tCO}_{2}-\mathrm{e}\right)$. The low rate of $\mathrm{AN}$ was the least effective mitigation option $\left(32.7 \mathrm{t} \mathrm{CO}_{2}-\mathrm{e}\right)$. The three high (or low) $\mathrm{NO}_{3}$ supplements supply the same amount of dietary $\mathrm{N}$, but contain different amounts of $\mathrm{NO}_{3}$, resulting in variation in the amount of mitigation.

An example distribution of GM/AE and RoC showing the standard deviations from 10000 iterations is shown for the low CAN (CANL) option in Fig. 1. Similar graphs were used to generate the comparative values for all the other supplementation treatments. As there were 10000 iterations, the standard errors of differences between the GM/AE and RoC means of all options were very low, making most differences among means highly significant. The 5th and 95th percentiles for the CANL option were AU\$137.27 and AU\$223.94 and $0.31 \%$ and $2.72 \%$ for $\mathrm{GM} / \mathrm{AE}$ and RoC, respectively.

The GM/AE and RoC distributions sorted in rank order of mean are given in Table 2.

The best GM/AE and RoC were achieved by the very high CSM supplementation options (which included urea supplementation of kept females). The next best options were supplementation with low CSM or either high or low CAN, followed by high CSM, followed by low rates of urea or AN. Supplementing with CN had the lowest GM/AE. However, no supplementation option returned more than the target $2 \%$ RoC, although the CSM strategies were close $(1.93 \%$ RoC).

The sensitivities of the impact of distribution parameters on GM/AE and RoC for each option are calculated by @risk. The ranges of $\mathrm{GM} / \mathrm{AE}$ and $\mathrm{RoC}$ values were most sensitive to the net price received per kilogram LW for sale steers. The price of supplement was the most important criterion when comparing the $\mathrm{NO}_{3}$ supplement options, especially when modelled to be fed at greater amounts. The returns were relatively insensitive to the carbon price or estimated mitigation, compared with the price per kilogram of stock sold.

The carbon and supplement prices needed to achieve a $2.0 \%$ RoC for options estimated by goal seeker analysis in @ risk are shown in Table 3.

The size of the differences between current carbon price (AU $\$ 10$ t CO2-e) and current supplement prices and their goal seeker prices in Table 3 indicates how much prices would need to change

Table 1. Greenhouse gas production ( $\mathrm{CO}_{2}$-e) for the baseline (urea) and alternative supplementation options Different letters indicate that the values are significantly different (at $P=0.05$ ). $\mathrm{CN}$, calcium nitrate; AN, ammonium nitrate; CAN, calcium ammonium nitrate; CSM, cottonseed meal; LW, liveweight

\begin{tabular}{|c|c|c|c|c|}
\hline $\begin{array}{l}\text { Supplementation } \\
\text { option }\end{array}$ & Enteric methane & $\begin{array}{l}\text { Total emissions } \\
\text { (t CO2-e) }\end{array}$ & Mitigation & $\begin{array}{l}\text { Emission intensity } \\
\text { (t CO } \mathrm{CO}_{2} \text {-e/t LW sold) }\end{array}$ \\
\hline Low urea & 2872.5 & 3001.0d & & 10.6 \\
\hline High urea & 2872.5 & 3001.0d & & 10.3 \\
\hline Low CN & 2766.9 & $2898.0 \mathrm{~g}$ & 103.0 & 10.2 \\
\hline High CN & 2679.7 & $2810.5 \mathrm{~h}$ & 190.5 & 9.7 \\
\hline Low AN & 2837.0 & $2968.3 \mathrm{e}$ & 32.7 & 10.5 \\
\hline High AN & 2801.5 & $2932.7 f$ & 68.3 & 10.1 \\
\hline Low CAN & 2774.4 & $2905.5 \mathrm{~g}$ & 95.5 & 10.3 \\
\hline High CAN & 2692.0 & $2822.9 \mathrm{~h}$ & 178.1 & 9.7 \\
\hline Low CSM & 2872.5 & $3051.0 \mathrm{c}$ & $53.3^{\mathrm{A}}$ & 10.4 \\
\hline High CSM & 2872.5 & $3070.7 b$ & $73.1^{\mathrm{A}}$ & 10.1 \\
\hline Very high CSM & 2872.5 & $3110.0 \mathrm{a}$ & $112.4^{\mathrm{A}}$ & 9.9 \\
\hline
\end{tabular}

${ }^{\mathrm{A}}$ Calculated as urea (baseline) $\left(\mathrm{t} \mathrm{CO}_{2}-\mathrm{e}\right) \times$ total $\mathrm{LW}(\mathrm{kg})$ sold project / total $\mathrm{LW}(\mathrm{kg})$ sold baseline. 
(a)

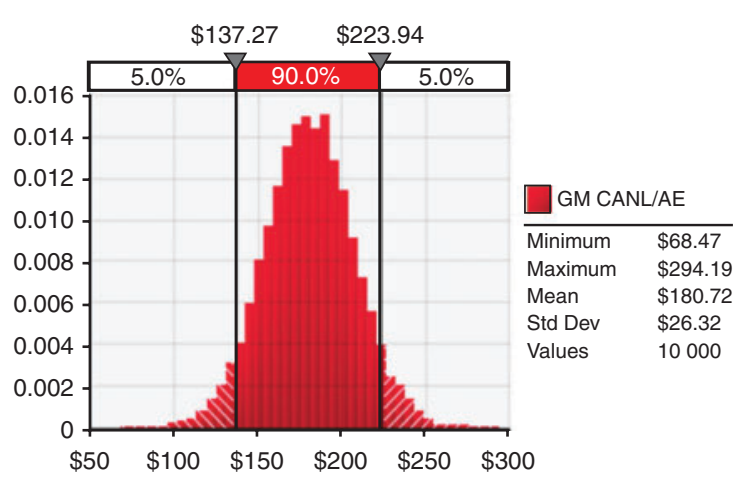

(b) RoCCANL

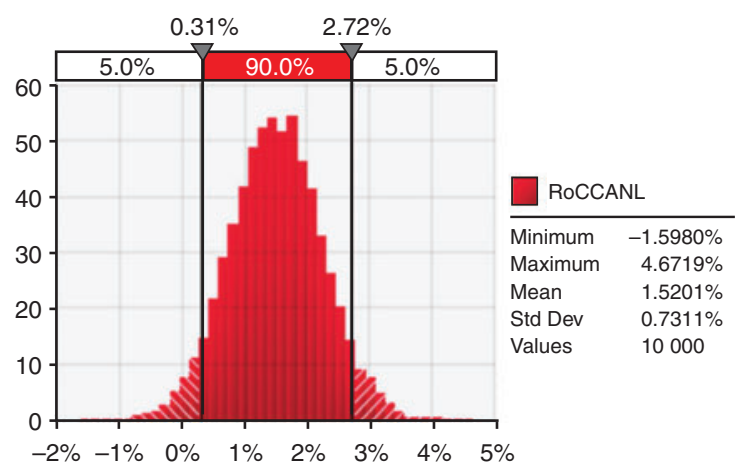

Fig. 1. Example distribution of (a) gross margin/adult animal equivalent (GM/AE) and (b) return on capital (RoC), for the low level of calcium ammonium nitrate (CANL) supplementation.

Table 2. Gross margin/adult equivalent (GM/AE) and return on capital (RoC) distributions (mean, $5 \%$ and $95 \%$ tails) for the options in rank order of the mean

Different letters indicate that the values are significantly different (at $P=0.05$ )

\begin{tabular}{lcccccr}
\hline $\begin{array}{l}\text { Supplementation } \\
\text { option }\end{array}$ & Mean & $\begin{array}{c}\text { GM/AE }(\$) \\
5 \%\end{array}$ & $95 \%$ & Mean & $5 \%$ & $95 \%$ \\
\hline Very high CSM & $195.62 \mathrm{a}$ & 148.34 & 243.01 & 1.93 & 0.62 & 3.25 \\
Low CSM & $195.43 \mathrm{ab}$ & 151.69 & 239.77 & 1.93 & 0.71 & 3.16 \\
Low CAN & $194.77 \mathrm{~b}$ & 152.23 & 237.27 & 1.91 & 0.73 & 3.09 \\
High CAN & $194.63 \mathrm{~b}$ & 150.44 & 238.55 & 1.91 & 0.68 & 3.13 \\
High CSM & $192.85 \mathrm{c}$ & 145.83 & 239.39 & 1.86 & 0.55 & 3.15 \\
Low AN & $190.40 \mathrm{~d}$ & 147.30 & 233.41 & 1.79 & 0.59 & 2.98 \\
Low urea & $190.23 \mathrm{~d}$ & 147.31 & 232.84 & 1.78 & 0.59 & 2.97 \\
High AN & $185.96 \mathrm{e}$ & 141.32 & 231.13 & 1.67 & 0.43 & 2.92 \\
High urea & $185.61 \mathrm{e}$ & 140.82 & 230.70 & 1.66 & 0.41 & 2.91 \\
Low CN & $166.17 \mathrm{f}$ & 122.13 & 210.46 & 1.11 & -0.11 & 2.34 \\
High CN & $137.41 \mathrm{~g}$ & 86.62 & 188.69 & 0.32 & -1.09 & 1.74 \\
\hline
\end{tabular}

Table 3. Carbon and supplement prices required to achieve a $\mathbf{2 . 0 \%}$ return on capital (RoC)

Average carbon price was AU $\$ 10 / \mathrm{CO}_{2}$-e

\begin{tabular}{lcc}
\hline $\begin{array}{l}\text { Supplementation } \\
\text { option }\end{array}$ & $\begin{array}{c}\text { Carbon price } \\
\text { for } 2.0 \% \text { RoC } \\
\left(\mathrm{AU} \$ / \mathrm{t} \mathrm{CO}_{2}-\mathrm{e}\right)\end{array}$ & $\begin{array}{c}\text { Supplement price } \\
\text { for } 2.0 \% \text { RoC } \\
\text { (AU\$/t as fed: } \\
\text { AU\$/t N) }\end{array}$ \\
\hline Low urea & n.a. & $325: 2355$ \\
High urea & n.a. & $452: 3275$ \\
Low CN & 726 & $145: 2427$ \\
High CN & 744 & $209: 3498$ \\
Low AN & 683 & $338: 2415$ \\
High AN & 562 & $466: 3329$ \\
Low CAN & 372 & $702: 2600$ \\
High CAN & 726 & $540: 2000$ \\
Low CSM & 107 & $<0$ \\
High CSM & 151 & $<0$ \\
Very high CSM & 52 & $27: 392$ \\
\hline
\end{tabular}

to achieve a $2 \%$ RoC. Higher required carbon prices or low supplement prices indicate less profitable options. The CSM (and urea) options had the lowest carbon price (AU\$52-151), while the
$\mathrm{CN}$ and CAN had the highest carbon price required (AU \$726-744). The CAN options required the largest change in supplement prices. The low (negative) CSM supplement prices indicate that changing the CSM price would not achieve a $2 \% \mathrm{RoC}$ if the carbon price averaged $\mathrm{AU} \$ 10 / \mathrm{tCO}_{2} \mathrm{e}$. This was due to the low total cost of CSM supplement for the 1 yo steers relative to the total cost of urea supplementation of all stock other than the steers in this strategy.

\section{Discussion}

\section{Cattle production on native speargrass pastures} and extension of results to other areas

Nitrogen supplementation can be of benefit during the dry winter-spring months when average pasture quality is low $(0.64-0.96 \% \mathrm{~N} ; 4-6 \%$ crude protein) in Queensland and the Northern Territory (Dixon 2011; Bray et al. 2015). Therefore, the supplementation strategies discussed are potentially applicable to a large proportion of the 13 million head cattle herd in northern Australia, depending on the cost: benefit of supplementation. Feeding during the dry season is also less hampered by access via unsealed roads. Although urea feeding is relatively common in northern Australia, it is often not utilised across whole herds. 
This may have an impact on whether a business can generate ACCU under prerequisite conditions of the current approved mitigation method.

\section{Relative mitigation and RoCs of options}

The most effective mitigation options, in terms of reduced quantity of $\mathrm{CO}_{2}-\mathrm{e}$, were those with high inclusions of $\mathrm{NO}_{3}$, with $\mathrm{CN}$ and CAN modelled to be fed to the breeder herd in winter-spring being the most effective and higher rates more effective than lower rates. As the diets are iso-nitrogenous and the response to $\mathrm{NO}_{3}$ is largely linear (Cottle and Eckard 2014), these results are expected due to the varying amount of $\mathrm{NO}_{3}$ in the different supplements. However, the $\mathrm{CN}$ and $\mathrm{CAN}$ were also the most expensive of the supplements, and ranked lowest in terms of GM/AE and RoC. This implies that the choice of NPN supplement (urea or $\mathrm{NO}_{3}$ ) should be based on the price per unit of $\mathrm{N}$ in the absence of a mitigation project, but also needs to consider the amount of mitigation $\left(\mathrm{NO}_{3}\right.$ content $)$ and carbon price in determining the profitability of undertaking a mitigation project. The maximum rate of $\mathrm{NO}_{3}$ allowed within the $\mathrm{NO}_{3}$ offset method, aimed at minimising $\mathrm{NO}_{3}$ toxicity risk, also limits the mitigation achievable.

At the scale of this case study (herd size 2000 AE), the ERF income (maximum mitigation was $191 \mathrm{tCO}_{2}$-e $\times \mathrm{AU} \$ 10 / \mathrm{tCO}_{2} \mathrm{e}=$ AU\$1910) was small and very unlikely to cover the ERF project costs. Cohn (2015) reported the costs of participating in an ERF project as about AU $\$ 100000$ over 7 years made up of AU\$10 000 (initial registration), AU\$3500 per annum (monitoring and sampling), AU\$5000 per annum (reporting), AU\$13 250 (initial audit fee), AU\$9000 per annum (ongoing audit) and AU\$1000 per annum (site visit fee). Costs associated with participation and compliance with the carbon farming initiative (CFI), the precursor to ERF, were valued at only AU\$2000 per year by Harrison et al. (2015), on the basis of Davison and Keogh's CFI report in 2011.

All except monitoring and sampling costs are fixed costs so they would substantially reduce the operating profit and $\mathrm{RoC}$ for all mitigation options. It is possible that larger corporate farming operations can achieve economies of scale to overcome the limitation of scale, or an aggregation agent could achieve cost sharing across farms.

Cottonseed meal modelled to be fed to steers in autumn, along with urea supplementation in winter and spring to other stock, was the best overall supplementation strategy, balancing mitigation and cost effectiveness, and was more cost effective than $\mathrm{NO}_{3}$ modelled to be fed to breeders in winter-spring. Therefore, the beef cattle herd management offset method that incentivises early finishing or increased weight gain may be viable in this region, as the supplementation with CSM was profitable in its own right. In addition, improved conception rates of first calf heifers, improved return to calf for second calf cows or earlier joining of heifers can result from supplementation (McGowan et al. 2014; Ash et al. 2015), but modelling these effects was beyond the scope of the present study. Given our analysis, it is unlikely that the nitrates and herd methodologies would be used together, first, because the nitrate method appears uneconomic unless the $\mathrm{NO}_{3}$ source has price parity with urea, and, second, because the CSM supplementation is clearly more economic and would provide protein in the diet, obviating the need for further $\mathrm{N}$ supplementation.

\section{Sensitivity and economic analyses}

Profitability was most sensitive to net price received per kilogram LW from livestock sales and was least sensitive to the carbon price. The coefficient of variation of $20 \%$ when applied to the average carbon price of $\mathrm{AU} \$ 10 / \mathrm{t} \mathrm{CO}_{2} \mathrm{e}$ was probably conservative. A higher variance would have increased the sensitivity of returns to carbon price. With this average carbon price, the gross income from offsets was between AU\$327 and AU $\$ 1905$ for the farm, with total GM (livestock and carbon) between AU\$256080 and AU\$391 240. Thus, offset income was between $0.1 \%$ and $0.7 \%$ of GM, being insufficient to incentivise uptake of this method at this scale. Another way to express this is that current carbon prices are between $1.9 \%$ and $3.8 \%$ of the price they would need to be to achieve a $2 \%$ RoC in the present case study. In contrast, CSM was profitable in terms of improved LW produced in the present case study, making this a potentially attractive option as the herd offset method rewards improved LWG or earlier turn-off of stock. EI of the very high CSM strategy was 4\% lower than the baseline urea strategy, so scale will also likely be an impediment to the uptake of this type of methodology.

The inclusion of an economic analysis, at least a GM and RoC, is important when evaluating offset options, to provide some indication of the prices required for the technology to be adopted. For example, the recent report by Hristov et al. (2015) on using 3-nitrooxypropanol to mitigate $\mathrm{CH}_{4}$ emissions indicated that it had a substantial mitigation impact, but did not include an economic analysis to indicate the economic viability of the method. An economic analysis should be undertaken to ensure that this approach has some chance of success, before allocating further investment in research resources. This is typical of many mitigation studies and is, therefore, by no means an isolated example of a lack of economic analysis. Some mitigation studies that have included economic analysis, such as Harrison et al. (2015), have studied only a few discrete levels of a few parameters, such as carbon price, whereas Monte Carlo simulations with distributions of parameters provide a more sophisticated approach to determining price sensitivities.

The level of complexity of the economic analysis is not a straight forward decision. More sophisticated models such as APSIM and GRASP can be used (e.g. Monjardino et al. 2015). However, when mitigation methods are orders of magnitude away from being profitable at existing carbon prices when using relatively simple economic models, it is debateable whether using more complex models would produce much more information about their likely practicality.

\section{Conclusions}

On the basis of the present case study, current carbon prices provide limited incentives to switch from supplementing urea to a $\mathrm{NO}_{3}$-based NPN source, unless the price per unit $\mathrm{N}$ is comparable and the economies of scale in the project are sufficient to absorb the ERF project overhead costs of running an offset method. In contrast, supplementing sale steers with CSM (and other cattle with urea) was profitable at current prices and the potential for offset income, based on improved weight gains and reduced turn-off time, could be an added bonus depending on ERF project overhead costs. While the use of a $\mathrm{NO}_{3}$ supplement 
may be widely applied across the northern Australian beef herd, the feeding of CSM in more remote regions may be limited due to increased transportation costs and the impact that widespread demand of CSM may have on future CSM prices. Further modelling may therefore need to focus on the herd size required to provide sufficient economies of scale and identify the regions in which these options may be profitable.

\section{Acknowledgements}

We thank Dr Stu McLennan, QAAFI, University of Queensland, for providing the growth equation for young steers on CSM, and Dr Rob Dixon, QAAFI, for providing growth estimates of stock on different amounts of urea. Dr Christie Ho and Ms Alexandria Sinnett from the Victorian Department of Economic Development, Jobs, Transport and Resources provided advice on using return on capital as an output parameter in addition to gross margin analyses. Thanks also go to Deb Corbet for suggestions that improved the manuscript.

\section{References}

Ash A, Hunt L, McDonald C, Scanlan J, Bell L, Cowley R, Watson I, McIvor J, MacLeod N (2015) Boosting the productivity and profitability of northern Australian beefenterprises: exploring innovation options using simulation modelling and systems analysis. Agricultural Systems 139, 50-65. doi:10.1016/j.agsy.2015.06.001

BoM (2015) 'Climate statistics for Australian locations.' Available at http:// www.bom.gov.au/climate/averages/tables/cw_039083.shtml [Verified 21 July 2015]

Bortolussi G, McIvor JG, Hodgkinson JJ, Coffey SG, Holmes CR (2005a) The northern Australian beef industry, a snapshot. 1. Regional enterprise activity and structure. Australian Journal of Experimental Agriculture 45, 1057-1073. doi:10.1071/EA03096

Bortolussi G, McIvor JG, Hodgkinson JJ, Coffey SG, Holmes CR (2005b) The northern Australian beef industry, a snapshot. 3. Annual liveweight gains from pasture based systems. Australian Journal of Experimental Agriculture 45, 1093-1108. doi:10.1071/EA03098

Bray S, Walsh D, Hoffmann M, Henry B, Eady S, Collier C, Pettit C, Navarro J, Corbet D (2015) 'Desktop research project to provide data on liveweight and liveweight gain in the beef cattle sector in Queensland and the Northern Territory.' (Department of Agriculture and Fisheries: Rockhampton, Qld)

Callaghan MJ, Tomkins NW, Benu I, Parker AJ (2014) How feasible is it to replace urea with nitrates to mitigate greenhouse gas emission from extensively managed beef cattle? Animal Production Science 54, $1300-1304$.

CER (2015a) 'Reducing greenhouse gas emissions by feeding nitrates to beef cattle.' Available at http://www.cleanenergyregulator.gov.au/ERF/ Choosing-a-project-type/Opportunities-for-the-land-sector/Agriculturalmethods/Reducing-greenhouse-gas-emissions-by-Feeding-Nitrates-toBeef-Cattle [Verified 21 July 2015]

CER (2015b) 'Emissions Reduction Fund auction results factsheet.' Available at http://www.cleanenergyregulator.gov.au/DocumentAssets/Pages/ Emissions-Reduction-Fund-auction-results-factsheet-November-2015. aspx [Verified 4 December 2015]

Charmley E, Williams SRO, Moate PJ, Hegarty RS, Herd RM, Oddy VH, Reyenga P, Staunton KM, Anderson A, Hannah MC (2016) A universal equation to predict methane production of forage-fed cattle in Australia. Animal Production Science, in press.

Coates DB, Dixon RM (2008) Faecal near infrared reflectance spectroscopy estimates of diet quality and responses to nitrogen supplements by cattle grazing Bothriochloa pertusa pastures. Australian Journal of Experimental Agriculture 48, 829-834. doi:10.1071/EA08004

Cohn P (2015) 'Can northern beef producers make money from the ERF?' Future beef webinar. (RAMP carbon). Available at https://futurebeefnew-
daff.netdna-ssl.com/wp-content/uploads/Can-producers-make-moneyfrom-the-ERF.pdf [Verified 10 August 2015]

Comlaw (2014) 'Carbon credits (Carbon Farming Initiative) (reducing greenhouse gas emissions by feeding nitrates to beef cattle) methodology determination 2014.' Available at https://www.comlaw.gov.au/Details/ F2014L01129 [Verified 10 August 2015]

Cottle DJ, Eckard R (2014) Modelling the reduction in enteric methane from voluntary intake versus controlled individual animal intake of lipid or nitrate supplements. Animal Production Science 54, 2121-2131.

Cottle DJ, Wyld R (2014) Multi-bin bunker systems to control delivery of supplements to individual grazing animals. In 'Proceedings 17th symposium on precision agriculture Australasia'. (Ed. B Whelan) pp. 45-50. (University of Sydney: Sydney)

Cottle DJ, Nolan JV, Wiedemann SG (2011) Ruminant enteric methane mitigation: a review. Animal Production Science 51, 491-514. doi:10.1071/AN10163

CQLX (2015) 'Central Queensland livestock exchange.' Available at http:/ www.cqlx.com.au/reports.html [Verified 10 August 2015]

DAF (2015a) 'Future beef. Land types.' Available at http://www.futurebeef. com.au [Verified 10 August 2015]

DAF (2015b) 'Breedcow and Dynama software.' Available at https://www. daf.qld.gov.au/business-trade/business-and-trade-services/breedcow-anddynama-software [Verified 21 July 2015]

Dixon RM (2011) A meta-analysis of the responses to non-protein nitrogen supplementation by cattle grazing native pastures in the seasonally dry tropics. Advances in Animal Biosciences 2, 336.

Dixon RM (2013) Controlling voluntary intake of molasses-based supplements in grazing cattle. Animal Production Science 53, 217-225.

DoE (2015a) 'About the Emissions Reduction Fund.' Available at http:// www.environment.gov.au/climate-change/emissions-reduction-fund/about [Verified 3 August 2015]

DoE (2015b) 'Beef cattle herd management.' Available at http://www. environment.gov.au/climate-change/emissions-reduction-fund/methods/ beef-cattle-herd-management [Verified 21 July 2015]

Eckard RJ (1990) The relationship between the nitrogen and nitrate content and nitrate toxicity potential of Lolium multiflorum. Journal of the Grassland Society of South Africa 7, 174-178. doi:10.1080/02566702.1990.9648227

Harrison MT, McSweeney C, Tomkins NW, Eckard RJ (2015) Improving greenhouse gas emissions intensities of subtropical and tropical beef farming systems using Leucaena leucocephala. Agricultural Systems 136, 138-146. doi:10.1016/j.agsy.2015.03.003

Hennessy DW, Williamson PJ, Darnell RE (2000) Feed intake and liveweight responses to nitrogen and/or protein supplements by steers of Bos taurus, Bos indicus and Bos taurus $\times$ Bos indicus breed types offered a low quality grass hay. The Journal of Agricultural Science 135, 35-45. doi:10.1017/S0021859699007923

Holmes WE (2012) Breedcowplus software package, Version 6.0. Training Series QE99002. Queensland Department of Primary Industries and Fisheries, Townsville, Qld.

Hristov AN, Oh J, Giallongoa F, Frederick TW, Harper MT, Weeks HL, Branco AF, Moate PJ, Deighton MH, Williams SRO, Kindermann M, Duvale S (2015) An inhibitor persistently decreased enteric methane emission from dairy cows with no negative effect on milk production. Proceedings of the National Academy of Sciences 112, $10663-10668$. doi:10.1073/pnas. 1504124112

Hulshof RBA, Berndt A, Gerrits WJJ, Dijkstra J, van Zijderveld SM, Newbold JR, Perdok HB (2015) Dietary nitrate supplementation reduces methane emission in beef cattle fed sugarcane-based diets. Journal of Animal Science 90, 2317-2323. doi:10.2527/jas.2011-4209

Landmark (2015) 'Benchmark.' Available at http://photos.harcourts.com.au/ Harcourts.Public.WebTemplates/602/Files/CL_LandmarkHarcourts_ BenchmarkReport_SeventhEd_web-2.jpg [Verified 25 September 2015]

Leng RA (2008) The potential of feeding nitrate to reduce enteric methane production in ruminants. A report to the Department of Climate Change. Commonwealth Government of Australia, Canberra. Available at http:// 
www.penambulbooks.com/Downloads/Leng-FinalModified2017-92008.pdf [Verified 10 August 2015]

McCown RL (1980-1981) The climatic potential for beef cattle production in tropical Australia: part 1 - simulating the annual cycle of liveweight change. Agricultural Systems 6, 303-317. doi:10.1016/0308-521X(81) 90065-2

McGowan MR, McCosker KD, Fordyce G, Smith DR, O'Rourke PK, Perkins N, Barnes T, Marquart L, Morton J, Newsome T, Menzies D, Burns BM, Jephcott S (2014) Northern Australian beef fertility project: CashCow. B.NBP.0382. Final report prepared for Meat and Livestock Australia, Sydney.

McLean I, Holmes P, Counsell D (2014) The northern beef report 2013. Northern beef situation analysis. Meat and Livestock Australia, Sydney.

McLennan SR (2004) More effective supplements for the northern beef industry. Project number NAP3.122. Final report prepared for Meat and Livestock Australia, Sydney.

McLennan SR (2014) Optimising growth paths of beef cattle in northern Australia for increased profitability. B.NBP.0391. Final report prepared for Meat and Livestock Australia, Sydney.

Monjardino M, MacLeod N, McKellar L, Prestwidge D (2015) Economic evaluation of irrigated forage production in a beef cattle operation in the semi-arid tropics of northern Australia. Agricultural Systems 139, 122-143. doi:10.1016/j.agsy.2015.07.004
Murphy K (1995) 'Beef production systems.' (Tropical Beef Centre: Rockhampton, Qld)

Palisade (2015) '@risk.' Available at http://www.palisade.com/risk/ [Verified 21 July 2015]

Poppi DP, McLennan SR (1995) Protein and energy utilization by ruminants at pasture. Journal of Animal Science 73, 278-290.

Risco CA, Holmberg CA, Kutches A (1992) Effect of graded concentrations of gossypol on calf performance: toxicological and pathological considerations. Journal of Dairy Science 75, 2787-2798. doi:10.3168/ jds.S0022-0302(92)78042-4

Tothill JC, Gillies C (1992) 'The pasture lands of northern Australia.' Occasional publication no. 5. (Tropical Grassland Society of Australia: Brisbane)

UNFCCC (2015) 'National inventory submissions 2015.' Available at https://unfccc.int/national_reports/annex_i_ghg_inventories/national_ inventories_submissions/items/8812.php [Verified 21 July 2015]

Ungerfeld EM, Kohn RA (2006) The role of thermodynamics in the control of ruminal fermentation. In 'Ruminant physiology'. (Eds K Sejrsen, $\mathrm{T}$ Hvelplund, MO Nielsen) pp. 55-85. (Wageningen Academic Publishers: Wageningen, The Netherlands)

van Zijderveld SM, Gerrits WJJ, Dijkstra J, Newbold JR, Hulshof RBA, Perdok HB (2011) Persistency of methane mitigation by dietary nitrate supplementation in dairy cows. Journal of Dairy Science 94, 4028-4038. doi:10.3168/jds.2011-4236 